Available online at: http://ejournal-balitbang.kkp.go.id/index.php/ifrj
e-mail:ifrj.puslitbangkan@gmail.com
INDONESIAN FISHERIES RESEARCH JOURNAL
Volume 25 Nomor 2 December 2019
p-ISSN: 0853-8980
e-ISSN: 2502-6569
Accreditation Number RISTEKDIKTI: 21/E/KPT/2018

\title{
CORAL REEF CONDITION IN RELATION TO CORAL REEF FISH ABUNDANCES BEFORE MASS BLEACHING EVENT IN SIMEULUE ISLANDS, ACEH
}

\author{
Ulung J. Wisha ${ }^{\star 1}$, Koko Ondara ${ }^{1}$, Wisnu A. Gemilang ${ }^{1}$, Guntur A. Rahmawan ${ }^{1}$, Ruzana Dhiauddin ${ }^{1}$ and IIham ${ }^{1}$ \\ ${ }^{1}$ Research Institute for Coastal Resources and Vulnerability, Ministry of Marine Affairs and Fisheries, \\ Jl. Raya Padang-Painan Km. 16 Bungus, Padang, Sumatera Barat-Indonesia \\ Received; February 02-2018 Received in revised from October 22-2018; Accepted January 07-2019
}

\begin{abstract}
Bordered with the Indian Ocean, Simeulue Islands is one of the outermost islands in Indonesia located in the west part of Aceh Province. Simeulue waters are productive areas due to the unpolluted water condition and great biomass. Three regions were particularly observed, those are Simeuluecut, Ganting, and Labuhan Bajau. At those there areas, the existing marine tourism activities might affect to coral reef ecosystem. This study aimed to evaluate the condition of coral and coral reef fish in those three particular regions before mass bleaching event in 2016 triggered by ENSO. Point Intercept Transect (PIT) method was employed to record the percentage cover of coral, species diversity, and coral reef fish. Ganting waters was a moderate ecosystem area whith the percentage cover of coral was up to $45.62 \%$. However, in Simeuluecut and Labuhan Bajau waters, the coral reef communities were excellent with coral coverage reached $83.12 \%$ and 81.25 $\%$, respectively. The highest abundance genera of coral reef fish was observed in Simueluecut waters. This condition was changed oppositely in 2016 when the mass bleaching event accourred in Simeulue waters caused by temperature anomaly triggered by ENSO. The temperature raised almost $3^{\circ} \mathrm{C}$ for 6 months that undoubtedly induced bleaching whereby about $50 \%$ of coral colonies were dramatically declined in coral coverage and coral recruitment.
\end{abstract}

Keywords: Coral monitoring; coral reef fish; Simeuleu Islands; mass coral bleaching; ENSO

\section{INTRODUCTION}

Indonesian archipelago has affluent resources, which are specifically composed by great biomass (Plass-Johnson et al., 2016). Most of the outermost islands still have high in biodiversity than becoming the main marine resources that support the capture fisheries and aquaculture (Béné et al., 2016). One of the western-most islands is Simeulue that becomes the marine pivot in Aceh Province (Insacco \& Zava, 2017). The most attractive objects in Simeulue are coral reefs and coral reef fishes that are tremendously rich where the existence of coral reef fishes is related to the resource availability of coral reefs as its habitat (Rizwan et al., 2017).

Geographically, Simeulue islands is bordered by the Indian Ocean where the ocean-atmosphere interactions directly influences the water conditions in Simeulue waters (Herdiana et al., 2008). The crucial issue is temperature anomaly occurred in the Indian Ocean that may impact to coral reef ecosystem in the vicinity of Simeulue waters. The high temperature anomaly happened in the Indian Ocean region, yielding massive coral bleaching phenomenon, caused by ElNino Southern Oscillation (ENSO) and Indian Ocean Dipole (IOD) phenomena.

Three significant regions in Simeulue waters becoming the center of marine tourism are Ganting, Simueluecut, and Labuhan Bajau, where the greatest natural resources such as attractive beaches exist. Those areas have been becoming the most visited area by tourists. As the marine tourism destination, those areas are densely populated along the coastal area that directly contribute into the increase of anthropogenic wastes that may influence the coral and coral reef fish conditions (Baird et al., 2005; Campbell et al., 2007). Moreover, the unstable temperature due to climatic factors and the raising level of ocean acidification severely exacerbate the coral reef ecosystem (Guest et al., 2012; Bridge et al., 2014). 
Several previous related studies have been published. Herdiana et al. (2008) surveyed the coral reefs and coral reef fishes in Simeulue and Banyak Islands where the condition was great at that time. Water quality monitoring in Ganting Beach was conducted by Mutmainah et al. (2016). Therefore, a study regarding coral reefs and coral reef fishes in Simeulue Island is just preliminary. The previous reports were mostly focused on northern region of Aceh (Rudi et al., 2009; Ulfah, 2011; Baird et al., 2012; Fadli et al, 2014; Aldyza et al., 2015). According to the local fishermen in Simeulue, the most serious threats to the coral reefs in Ganting, Simueluecut, and Labuhan Bajau are marine pollution, fishing boats activities, and marine ecotourism.

Based on issues above, a study to assessing the condition before and after bleaching and identifying the anthropogenic pressure influencing coral reefs and coral reef fishes is essential. This study result might become a significant basis for the futher of Aceh Province development. Hence, this study aimed to evaluate the condition of coral and coral reef fish in Ganting, Simeuluecut, and Labuhan Bajau before mass bleaching occurred during the early 2016 triggered by ENSO. Point Intercept Transect method were used to survey coral reef condition by considering the percentage cover of coral, species diversity, and coral mortality indices. Furthermore coral reef fish identification was described by coral reef fish visual census.

\section{MATERIALS AND METHODS Study Sites}

The surveys were conducted in October $15^{\text {th }}, 2015$ and January $20^{\text {th }}, 2016$ in three main sites: Ganting, Simeulucut, and Labuhan Bajau (Figure 1). Both Ganting and Labuhan Bajau waters are located in the southeastern of Simeulue Islands where the surveys were positioned at $96.3616 \mathrm{E}, 2.5318 \mathrm{~N}$ and 96.5257 $\mathrm{E}, 2.4316 \mathrm{~N}$, respectively. Simeuluecut Island is located in the western part of Simeulue Islands that directly bordered with the Indian Ocean. In this area, the survey was positioned at $95.9603 \mathrm{E}, 2.5421 \mathrm{~N}$. Those three waters regions were known as represented areas of great biomass and coral reef ecosystem in Simeulue Islands. Therefore, monitoring and observation of coral reef and coral reef fish conditions to determine the occurrence of damage are essential.

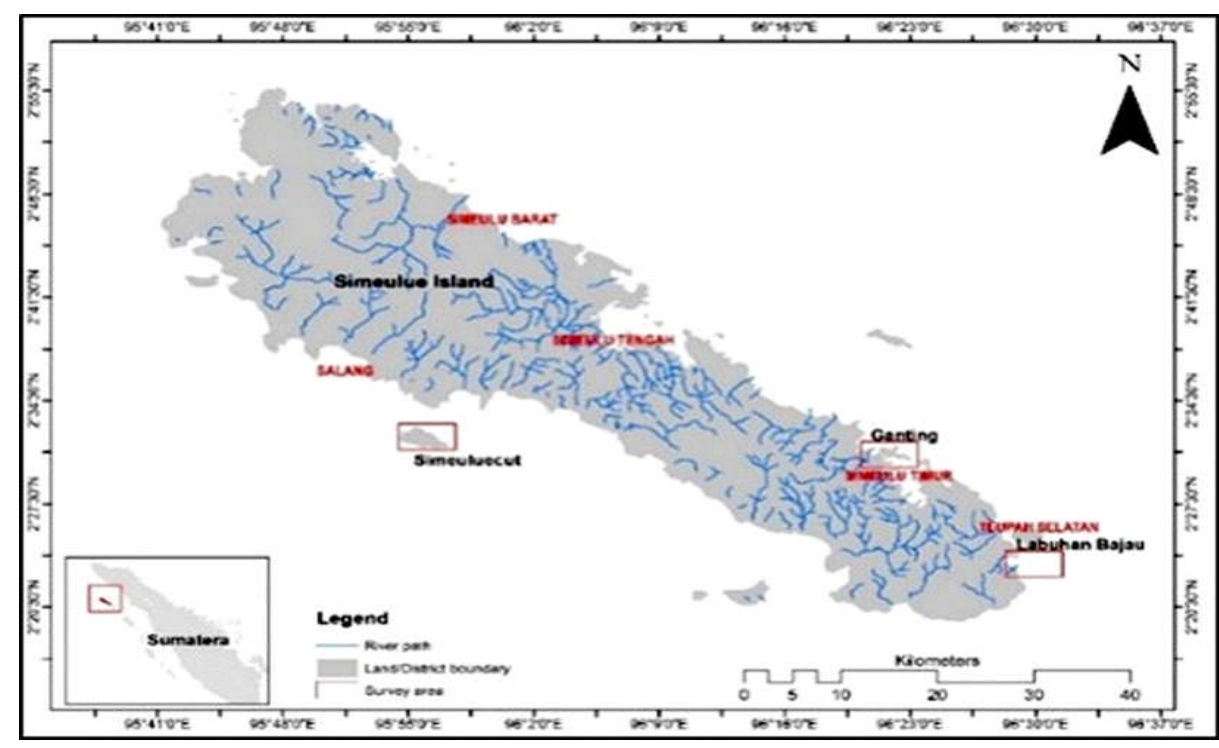

Figure 1. Survey locations in the Simeulue Island.

\section{Coral Assessment}

Coral reef and coral reef fish were observed using Point Intercept Transect (PIT) method. The PIT was employed to define the benthic community based on life form developed. Firstly, the site location was surveyed using manta tow method to find out the perfect area that will be monitored by establishing PIT. Sampling was carried out twice based on the two depths: 3-5 m and 6-10 m. The line transect was unfurled parallel to the coastline and kept in stable position to get the same depth observation area along $100 \mathrm{~m}$ each depth. Then the divers observed every biotathat passed based on its category and taxa. In this case, one colony is considered into one individual (Biddick et al., 2005).

Benthic habitat and the length of transitional cover observed along the $100 \mathrm{~m}$ transect line were grouped by their growth form. The coral percentage cover criteria are shown in Table 1. The calculation by applying the formula from was done to Miller et al. (2009) as follow: 
$\%$ cover $=\frac{\text { Total lenght of life from }(\mathrm{cm})}{\text { The lenght of btransect }(\mathrm{cm})} \times 100 \%$

Moreover, the calculation of the species diversity was done according to Shannon-Wiener formation (Spellerberg \& Fedor, 2003) as follow:

$$
H^{\prime}=\sum \frac{n i}{N x \log \frac{n i}{N}}
$$

where;

$H^{\prime}=$ diversity index

$\mathrm{N}=$ total amount of individual

$n i=$ total individual within $i$-species
The rate of damaged coral is related to the high rate of condition change (living and dead coral). Coral mortality ratio is obtained by calculating Mortality Index (MI) as follow:

$$
M I=\frac{\% \text { cover of corals }}{\% \text { dead and living corals }}
$$

The value of $M I$ determines the coral condition (Table 1). If the value of $M I$ is closer to 0 , it means that there is no change in the living coral community, whereas if the MIvalue is closer to 1 , it indicates that there is a high rate of mortality.

Table 1. Percentage cover and mortality index criteria

\begin{tabular}{cccc}
\hline Category & Percent cover $(\%)$ & Diversity index $\left(\boldsymbol{H}^{\prime}\right)$ & Mortality Index $(\mathbf{M I})$ \\
\hline Poor & $0-24.9$ & $H^{\prime}<1$ & $0.75-1$ \\
Fair & $25-49.9$ & $1<H^{\prime}<3$ & $0.5-9.749$ \\
Good & $50-74.9$ & $H^{\prime}>3$ & $0.25-0.499$ \\
Excellent & $75-100$ & - & $0-0.249$
\end{tabular}

Source: Ministry of Environment and Forestry, Indonesia, Regulation No. 4, 2011.

\section{Coral Reef Fishes Census}

At the same time with PIT survey, we conducted the census for coral fishes along the transect line. Underwater visual census method was employed to monitor coral reef fishes, particularly in remote locations (Sweatman et al., 2005). However, if it is possible, the transect should be combined with a long swim method providing more precise in the estimation of the abundance and biomass of large, high mobile species, patchy or clumped in distribution (Choat \& Pears, 2003).

Based on the coral fish census data, coral fishes are grouped into three groups according to its function and role. Those were target fish (economic and edible value fish as the target catch of fishermen), major fish (generally lives in coral reef ecosystem to protecting the balance of ecosystem), and indicator fish (indicating the coral health).

\section{RESULTS AND DISCUSSION Results}

\section{Percentage Cover of Coral and Coral Reef Fish Abundances}

Generally, Ganting waters are dominated by two main coral categories that are living coral nonAcropora $(\mathrm{HC})$ and dead coral that covered by filamentous algae (NIA/Nutrient Indicator Alga) (Figure 2). Several genera identified in Ganting waters were Porites, Acropora, Pavona, Fungia, Favia, Galaxea, and Pocillopora. Ganting waters are categorized into moderate ecosystem according to percentage cover up to $47.25 \%$. Dead coral with filamentous algae was observed reaching $43.125 \%$.

In Simeulucut waters, living hard coral had high percentage mainly in the ecosystem that up to $83.125 \%$, while the other living cover is placed by soft coral $(3.75 \%)$ and NIA (3.75\%). There are several genera identified along the line transect such as Porites, Acropora, Pavona, Fungia, Montopora, and Pocillopora as well (Figure 2).

In Labuhan Bajau, the hard coral reached $81.25 \%$ (still highly covered). The other biota, except for nonliving coral, were observed, such as soft coral, NIA, and sponge, which reached $0.625 \%, 15.625 \%$, and $1.875 \%$, respectively. Commonly found coral genera in this site are Porites, Acropora, Pavona, Favites, Montipora, and Pocillopora beside non-coral living acidiant and sponge. Coral condition in Labuhan Bajau was categorized into excellent coral reef community because the percentage cover was very high $(82.875 \%)$.

Coral reef fishes identified in Ganting waters consisted of 50 genera belonging to 10 families. Three families of them that are mostly identified are Pomacentridae (17 genera), Chaetodontidae (14 genera), and Acanthuridae (7 genera). Major fishes in Ganting waters are mostly found reaching 50\% (25 genera), followed by indicator fish of $46 \%$ ( 23 genera) and the target fish was only $4 \%$ ( 2 genera). In the 
major fish group, Plectroglyphidodon lacrymatus, Dascyllus carneus, and Chromis caudalis are frequently high specimen number. Whereas, indicator fish families that mostly observed were Chaetodontidae and Labridae families. For target fish, only Zanclus cornutus (Figure 3) was observed.

In Simeulucut waters, about 50 genera of coral reef fishes belong to 9 families are observed. The mostly found families are Chaetodontidae (8 genera), Acanthuridae (9 genera), and Scaridae (9 genera). Generally, in Simeuluecut area, mostly found major fish reached $76 \%$ (38 genera), followed by indicator fish of $18 \%$ (9 genera), and the target fish $6 \%$ (3 genera). The major fish category consists of Plectroglyphidodon lacrymatus, Dascyllus carneus, and Chromis caudalis. Indicator fish consists of Chaetodontidae and Labridae, while Zanclus cornutus was the only target fish identified (Figure 3).

In Labuhan Bajau waters, 68 genera of coral reef fishes belonging to 12 families are identified. The main families are Chaetodontidae (14 genera), Acanthuridae (11 genera) and Scaridae (8 genera). The major fish reached $56 \%$ (38 genera) the frequently found taxa were Archamia macroptera (recently Taeniamia macroptera (Cuvier, 1828)) from family Apogonidae, and two other families: Pomacentridae and Mullidae. The indicator fish reached $23 \%$ (16 genera) from family Chaetodontidae and Labridae, while the target fish reached $21 \%$ (14 genera) the mostly found genera are Acanthurus auraticavus and Pterocaesio tile (Figure 3).

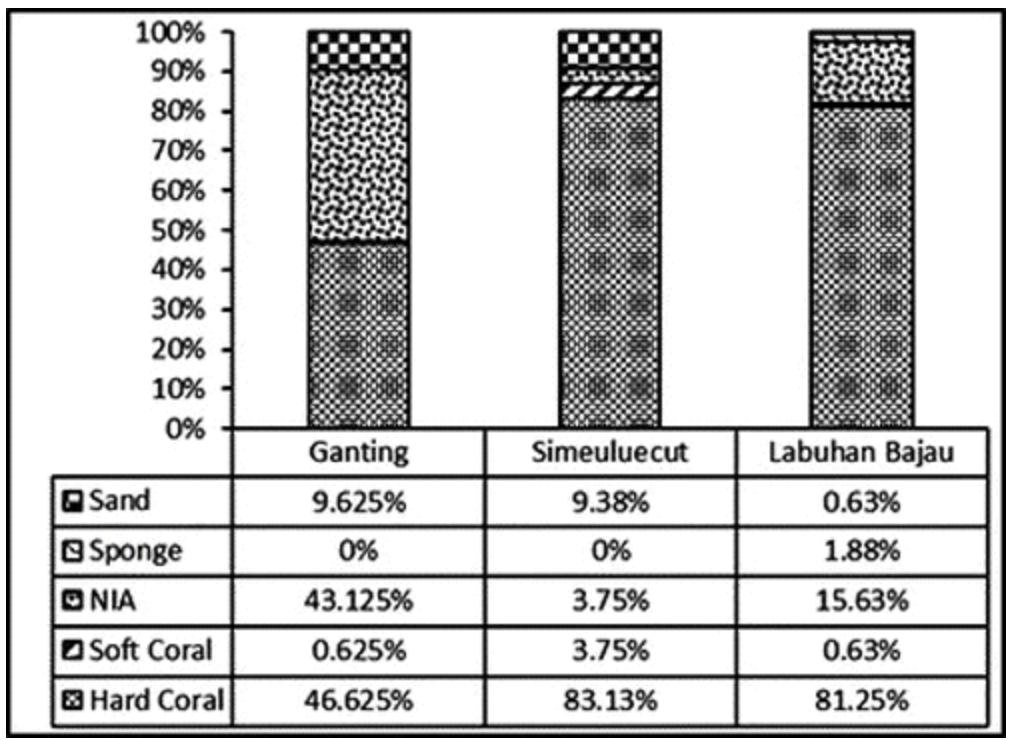

Figure 2. Percentage coral cover diagram at the three study sites.

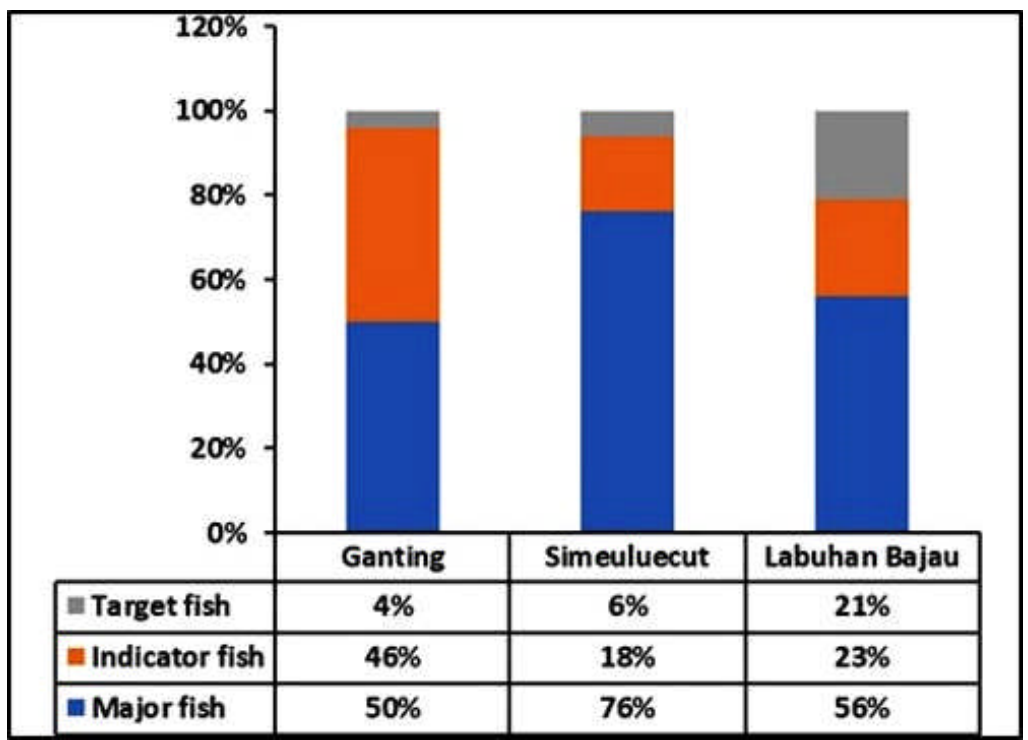

Figure 3. Fish abundance diagram at the three study sites. 


\section{Coral Mortality Indices (MI)}

Based on the calculation of percentage cover, Ganting waters is categorized into fair ecosystem area, while Simeuluecut and Labuhan Bajau are categorized into excellent ecosystem condition (Table 2). However, Coral Mortality Index $(M I)$ value for Ganting waters almost reached 1 (0.93). This high coral mortality indicated that the area was threatened by surrounding water conditions (such as water temperature, visibility, etc.) as limiting factors of coral grow and development. In this area, the coral percentage cover was $<50 \%$ but the diversity is still in moderate level. Fortunately, the MI values of Simeuluecut and Labuhan Bajau are low, indicated that the ecosystems are very suitable for supporting the coral reef fish survival ability as well its habitat.

Table 2. The analyzed value results from PIT survey

\begin{tabular}{lccc}
\hline Assessment aspects & Ganting waters & Simeuluecut Island & Labuhan bajau waters \\
\hline Percent cover & $46.25 \%$ (Fair) & $86.875 \%$ (Excellent) & 81.875 (Excellent) \\
Diversity index & $H^{\prime}=2.75$ (Fair) & $H^{\prime}=3.67$ (Good) & $H^{\prime}=3.36$ (Good) \\
Mortality index & 0.93 (Poor) & 0.04 (Excellent) & 0.18 (Excellent) \\
\hline
\end{tabular}

Coral Reef Ecosystem Conditions After Mass Bleaching Event

The temperature enhancement has been started inDecember 2015 and the maximum was in May 2016 that reached $30.55^{\circ} \mathrm{C}$ (Figure 4). Due to these changes, corals could not tolerant with the dramatically raising temperature (Baird et al., 2009; Brown, 1997; Hoegh-Guldberg, 1999) that caused coral bleaching in the Simeulue Islands in 2016. To correlate the ENSO's influence and increasing temperature phenomena in coral reef condition, the SOI (Southern Oscillation Index) was used to find the temperature oscillation pattern (Figure 5) using the differences on air pressure between Tahiti and Darwin (Ropelewski \& Jones, 1987). The ENSO's month is characterized by $\mathrm{SOl}<-10$ which directly influences temperature that might be supported by the Indian Ocean Dipole mode (Wisha \& Khoirunnisa, 2017).

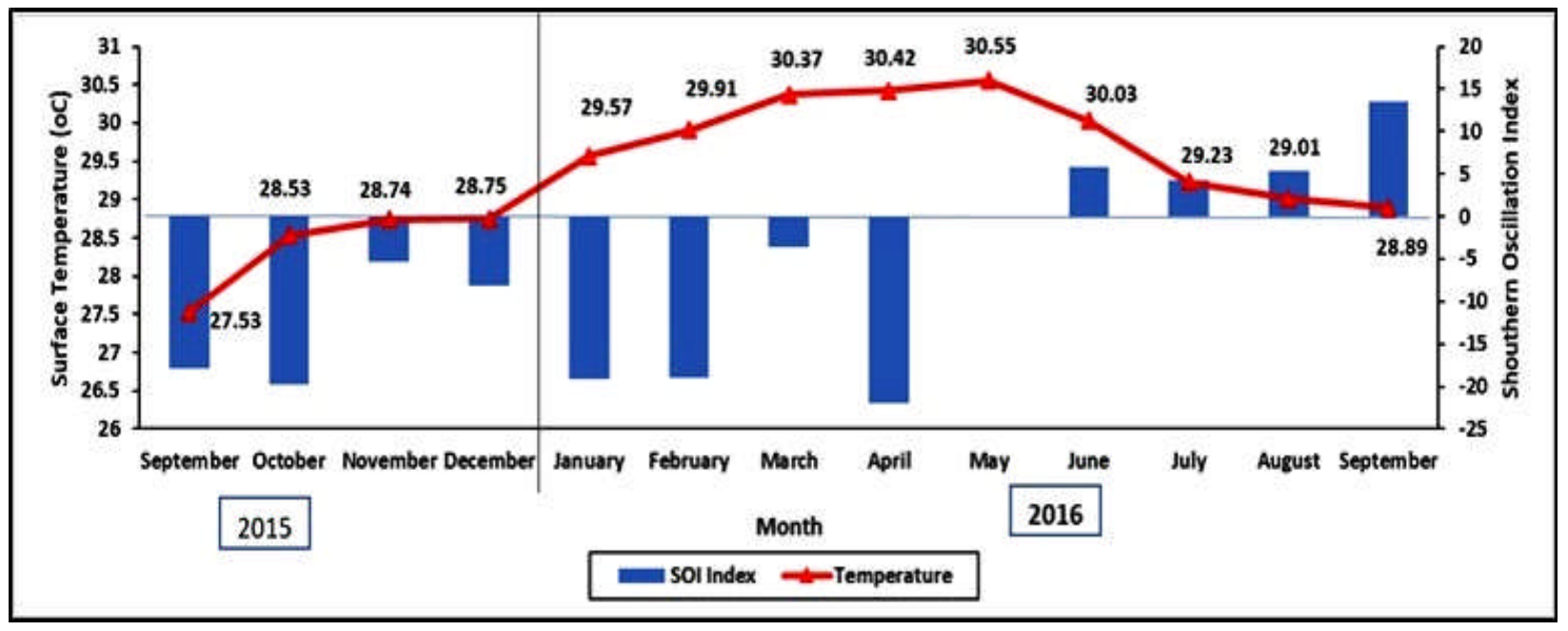

Figure 4. SOl index and the surface temperature correlation in Simuelue Island.

(Source: NOAA, 2016)

In general, the bleached coral colony was almost up to $50 \%$, pale condition reached $20 \%$, and in normal condition was $27 \%$, and the dead coral was observed up to $3 \%$ in all locations (Figure 5 ). The highest bleached coral colony was observed in Ganting waters, reaching $65 \%$, with coral mortality due to bleaching reached $5 \%$. Furthermore, $40 \%$ of the most normal coral condition were observed in Simeuluecut Island.
The implication of coral bleaching in Simeulue waters in 2016 was the dramatic coral reduction from $78 \% \pm 2.61 \mathrm{SE}$ in 2015 to $35 \% \pm 4.14 \mathrm{SE}$ in 2016 . It was also followed by the decreasing of coral recruitment from $6.5 \mathrm{ind} / \mathrm{m} \pm 1.04 \mathrm{SE}$ in 2015 to 1.37 ind $/ m \pm 0.16$ SE in 2016 (Figure 6). 


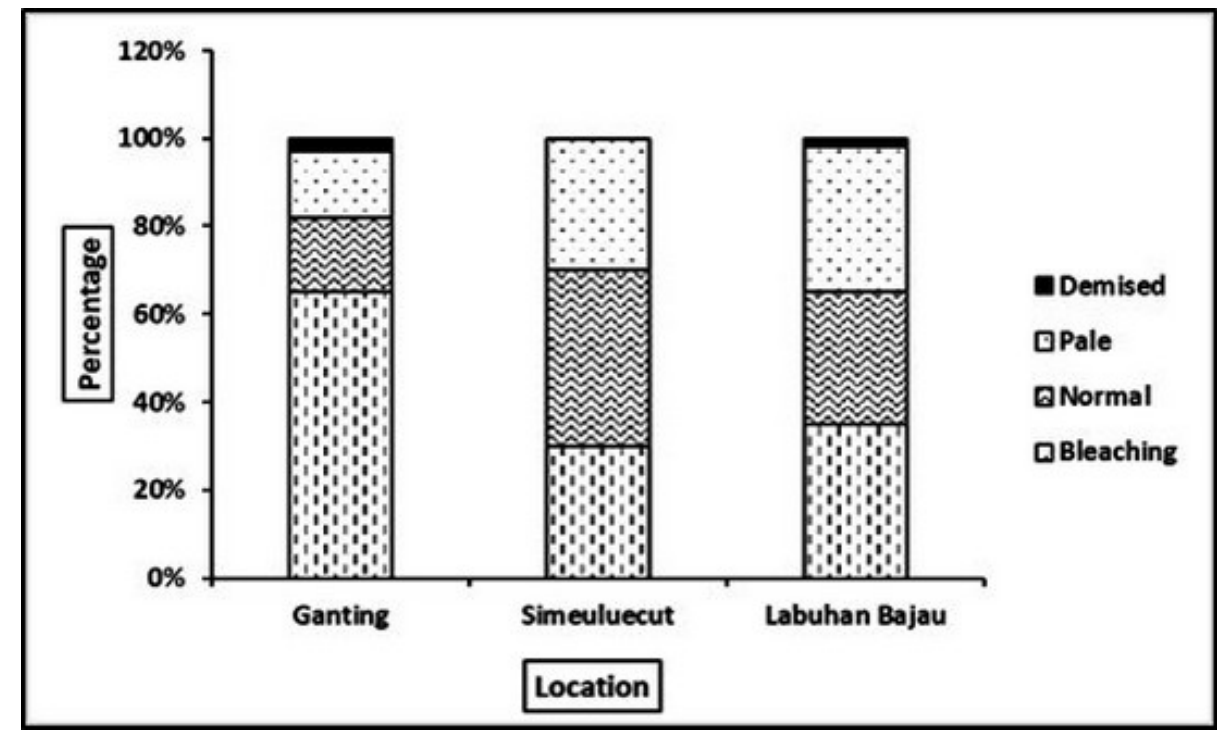

Figure 5. Diagrammatic histogram of coral bleaching in 2016.

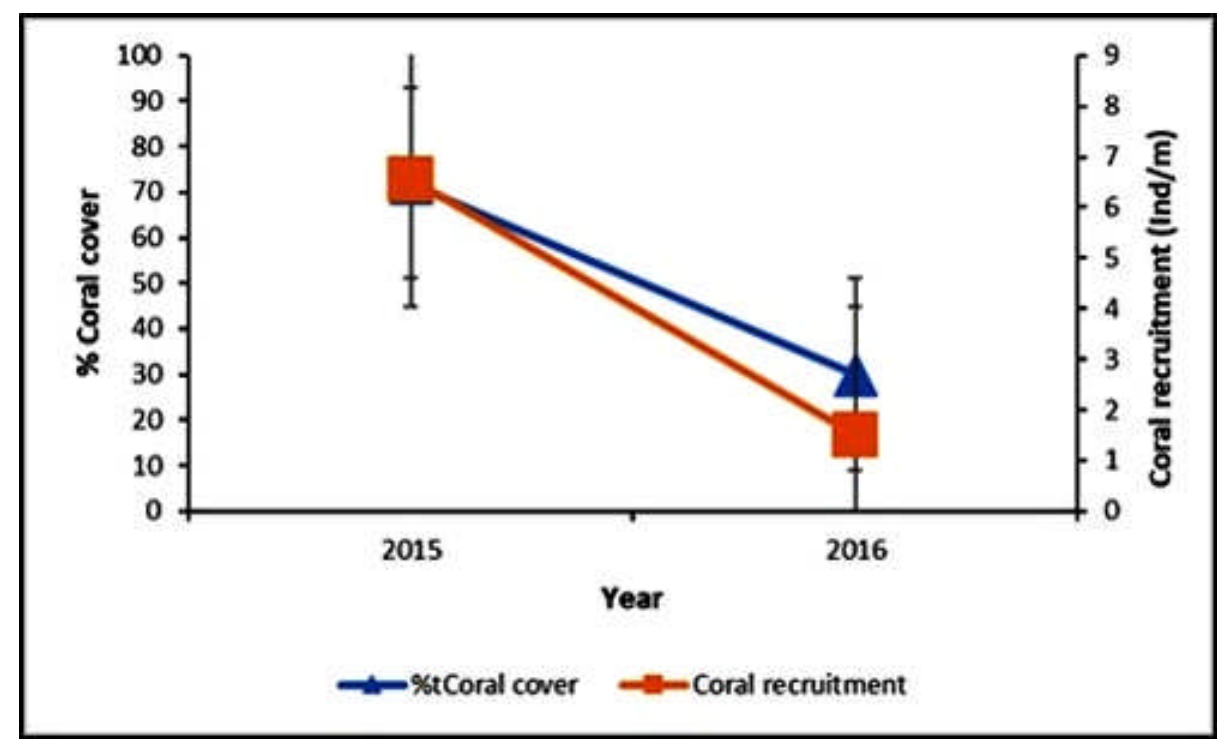

Figure 6. The average ( $\pm \mathrm{SE})$ coral cover percentage and coral recruitment in the Simeulue waters.

\section{Discussion}

\section{The Existing Condition of Coral Reefs and Fishes Before Mass Bleaching}

The coral reef condition in Ganting is getting worse (hard coral cover was $46.6 \%$ ) tcompared to Simeuluecut and Labuhan Bajau waters that were over $80 \%$. In Ganting and Labuhan Bajau waters, the anthropogenic pressures have been took place which may affect to wide-scale coral condition (Wooldridge, 2009).

Overall, coral reef fishes are in good condition, even though in Ganting waters the coral cover is lower than those in both Simeulucut and Labuhan Bajau. The fish abundances were still high, this probably supported by benthic macroalgae and the other organisms that becames the main food supply for especially herbivorous coral reef fishes (Lehahn et al., 2016). It is well known that coral fish abundance depends on the coral reef ecosystem as the place for living, spawning, and feeding (Pellissier et al., 2014). Coral reefs may face a diverse array of threats, from eutrophication and overfishing to climate change (Ritchie, 2006; Rosenberg \& Ben Haim, 2002; Harvell et al., 2002). This may have important consequences for the survival and growth of reef fish since complex habitats mediate prey interactions (Rogers et al., 2014).

Percentage coral cover condition that has been shown in 2015 indicated that the coral reef ecosystem was in a good condition. Diversity index shows the 
same pattern, in which Ganting waters was moderately diverse, compared to Simueluecut and Labuhan Bajau that have an excellent category of coral diversity. It is because Ganting waters was suffered by a physical pressure due to preoccupied human activity in the coastal area, whereas Simeuluecut and Labuhan Bajau are remote areas with low of anthropogenic pressure.

\section{Coral Reefs Conditions After Mass Bleaching}

The lesser the value of SOI, the higher the temperature observed (Figure 4). Obviously, in fact that those conditions result in bleached and dead corals in Simeulue that may impact on ecosystem, such as coral reef fish and other biota. The recruitment of young corals has a significant role in the recovery and decolonization after bleaching. The genera of young corals that are able to survive and recover can give a significant impact to the coral community structure substantially (Westmacott et al., 2000).

Due to the coral cover and recruitment reductions, the fish abundance and biomass may also decline. The dead coral impacts the coral reef fish that depend on the coral reef ecosystem. The coral reef fish are difficult to get their food and shelter due to bleaching (Pratchett et al., 2013). Coral reefs provide homes and protection from predators, especially for small types of fish that affect the pattern of their survival and abundance (Eggleston, 1995). Coral fish and coral reefs have a close relationship in the process of coevolution, where reef fish grow and develop along with the development of coral reefs as their habitat (Muttaqin et al., 2014). Commonly, the coral genera that were found with bleached condition were Acropora and Pocillopora. According to Prachett et al. (2013), Acropora and Pocillopora are the most vulnerable genera if the temperature increases.

The long-term impact of bleaching is if the physical structure of coral reefs is destroyed, it will result in decreased diversity of reef fish species (Garpe et al., 2006; Graham et al., 2007). The recovery process of post bleaching highly depends on the community diversity (Grimsditch \& Salm, 2006), especially the abundance of herbivorous fish that feed on algae (Hughes et al., 2006). Herbivorous fish play a role in reducing algae on the hard substrate, so that young and mature corals that are recovering the substrate would be more available to grow again. Postdisturbance hard coral recovery is directly proportional to the recovery of the coral reef fish community (Emslie et al., 2008). The recovery of hard coral after bleaching can occur if there is no intervention interference during its recovery (Pratchett et al., 2013).

\section{CONCLUSION}

Coral reef ecosystem observed in Simeulue, Aceh, is categorized into a good condition, which consist of abundant fish and other biota, and the high coverage of coral. This condition is supported by water quality surrounding the coral area that is very suitable for coral growth. Ganting waters is worse than Simeuluecut and Labuhan Bajau because of the pressure of anthropogenic activities such as fishing and marine tourism that was very preoccupied in that region. Simeuluecut and Labuhan Bajau are categorized into an excellent water area with a high diversity, high coral coverage, and lower mortality. Coral reef fish abundances are very high especially in Simeuluecut that consist of $>50$ genera. Even though in Ganting waters the coral cover was lower than Simeulucut and Labuhan Bajau, the fish abundant is still high. This is probably caused by the high availability of benthic macroalgae and the other biota that are the main food supply supporting coral fish's growth. The condition was contrarily changed in 2016 , when the ENSO triggered high temperature-induced coral bleaching in several areas of Simeulue. The temperature increased almost $3^{\circ} \mathrm{C}$ for 6 month which undoubtedly induced bleaching reached $50 \%$ of coral colony causing a dramatic coral cover derivation. Due to coral coverage and recruitment reductions, the fish abundance and biomass may also decline. The dead coral colony had been impacted to the coral reef fishes then might affect to coral reef ecosystem as their habitat.

\section{ACKNOWLEDGMENT}

Our deepest gratitude is given to Research Institute for Coastal Resources and Vulnerability on APBNP research budget in Simeulue, Aceh Province, to Gunardi Kusumah as the research coordinator, and all those who have assisted in the completion of this scientific paper.

\section{REFERENCES}

Aldyza, N., Sarong, M. A., \& Rizal, S. (2015). Monitoring of hard coral covers and zonation of marine conservation area of Tuan Island, Aceh Besar District, Indonesia. Aquaculture, Aquarium, Conservation \& Legislation, 8(5), 640-647.

Baird, A.H., Campbell, S.J., Anggoro, A.W., Ardiwijaya, R.L., Fadli, N., Herdiana, Y., ... Siregar, A.M. (2005). Acehnese reefs in the wake of the Asian tsunami. Curr. Biol.,15: 1926-1930. https:// doi.org/10.1016/j.cub.2005.09.036. 
Baird, A. H., Bhagooli, R., Ralph, P. J., \& Takahashi, S. (2009). Coral bleaching: the role of the host. Trends in Ecology \& Evolution, 24(1), 16-20. https:/ /doi.org/10.1016/j.tree.2008.09.005.

Baird, A.H., Campbell, S.J., Fadli, N., Hoey, A.S., \& Rudi, E. (2012). The shallow water hard corals of Pulau Weh, Aceh Province, Indonesia. AACL Bioflux, 5 (1): 23-28.

Béné, C., Arthur, R., Norbury, H., Allison, E. H., Beveridge, M., Bush, S., Campling, L., Leschen, W., Williams, M. (2016). Contribution of fisheries and aquaculture to food security and poverty reduction: assessing the current evidence. World Development, 79, 177-196. https://doi.org/10.1016/ j.worlddev.2015.11.007.

Bridge, T. C., Hoey, A. S., Campbell, S. J., Muttaqin, E., Rudi, E., Fadli, N., \& Baird, A. H. (2014). Depthdependent mortality of reef corals following a severe bleaching event: implications for thermal refuges and population recovery. F1000Research, 2. https://doi.org/10.12688/f1000research.2-187.v1.

Brown, B. E. (1997). Coral bleaching: causes and consequences. Coral reefs, 16(1), S129-S138. https://doi.org/10.1007/s003380050249.

Campbell, S. J., Pratchett, M. S., Anggoro, A. W., Ardiwijaya, R. L., Fadli, N., Herdiana, Y., ...Rudi, E. (2007). Disturbance to coral reefs in Aceh, Northern Sumatra: impacts of the SumatraAndaman tsunami and pre-tsunami degradation. Atoll Research Bulletin, 544, 55-78.

Choat, H., Pears, R. (2003). A rapid, quantitative survey method for large, vulnerable reef fishes. In: Wilkinson, C., Green, A., Almany, J., and Dionne, S. Monitoring coral reef marine protected areas. A practical guide on how monitoring can support effective management of MPAs. Australian Institute of Marine Science and the IUCN Marine Program Publication. 68pp.

Eggleston, D. B. (1995). Recruitment in Nassau grouper Epinephelus striatus: post-settlement abundance, microhabitat features, and ontogenetic habitat shifts. Marine Ecology Progress Series, 124, 9-22. https://doi.org/10.3354/meps 124009.

Emslie, M. J., Cheal, A. J., Sweatman, H., \& Delean, S. (2008). Recovery from disturbance of coral and reef fish communities on the Great Barrier Reef, Australia. Marine Ecology Progress Series, 371, 177-190. https://doi.org/10.3354/meps07657.
Fadli, N., Kunzmann, A., von Jutarzenka, K., Rudi, E., \& Muchlisin, Z. A. (2014). A preliminary study of corals recruitment using coral rubbles substrate in Seribu Island waters, Indonesia. Aquaculture, Aquarium, Conservation \& Legislation-International Journal of the Bioflux Society (AACL Bioflux), 6(3), 246-232. https://doi.org/10.1016/ j.margeo.2014.09.047.

Garpe, K. C., Yahya, S. A., Lindahl, U., \& Öhman, M. C. (2006). Long-term effects of the 1998 coral bleaching event on reef fish assemblages. Marine Ecology Progress Series, 315, 237-247. https:// doi.org/10.3354/meps315237.

Graham, N. A., Wilson, S. K., Jennings, S., Polunin, N. V., Robinson, J. A. N., Bijoux, J. P., \& Daw, T. M. (2007). Lag effects in the impacts of mass coral bleaching on coral reef fish, fisheries, and ecosystems. Conservation biology, 21(5), 1291 1300. https://doi.org/10.1111/j.15231739.2007.00754.x.

Grimsditch, G. D., \& Salm, R. V. (2006). Coral reef resilience and resistance to bleaching. IUCN, The World Conservation Union.

Guest, J. R., Baird, A. H., Maynard, J. A., Muttaqin, E., Edwards, A. J., Campbell, S. J., ...Chou, L. M. (2012). Contrasting patterns of coral bleaching susceptibility in 2010 suggest an adaptive response to thermal stress. PloS one, 7(3), e33353. journal.pone.0033353.

Harvell, C. D., Mitchell, C. E., Ward, J. R., Altizer, S., Dobson, A. P., Ostfeld, R. S., \& Samuel, M. D. (2002). Climate warming and disease risks for terrestrial and marine biota. Science, 296(5576), 2158-2162. https://doi.org/10.1126/ science.1063699.

Herdiana, Y., Kartawijaya, T., Ardiwijaya, R. L., Setiawan, F., Prasetia, R., Pardede, S. T., \& Campbell, S. J. (2008). Ecological survey on coral reefs of Simeulue and Banyak Islands-Aceh 2007. Wildlife Conservation Society-Indonesia Marine Program, Bogor, Indonesia.

Hoegh-Guldberg, O. (1999). Climate change, coral bleaching and the future of the world's coral reefs. Marine and freshwater research, 50(8), 839-866. https://doi.org/10.1071/MF99078.

Insacco, G., \& Zava, B. (2017). Chlorurus rhakoura Randall \& Anderson, 1997 (Perciformes, Scaridae), 
an Indo-Pacific fish new for the Mediterranean Sea. Mediterranean Marine Science, 18(2), 285-291. http://dx.doi.org/10.12681/mms.2139.

Lehahn, Y., Ingle, K. N., \& Golberg, A. (2016). Global potential of offshore and shallow waters macroalgal biorefineries to provide for food, chemicals and energy: feasibility and sustainability. Algal Research, 17, 150-160. https://doi.org/10.1016/ j.algal.2016.03.031.

Miller, J., Muller, E., Rogers, C., Waara, R., Atkinson, A., Whelan, K. R. T., ... Witcher, B. (2009). Coral disease following massive bleaching in 2005 causes $60 \%$ decline in coral cover on reefs in the US Virgin Islands. Coral Reefs, 28(4), 925. https:/ /doi.org/10.1007/s00338-009-0531-7.

Mutmainah, H., Kusumah, G., Altanto, T., \& Ondara, K. (2016). An environmental suitability study for tourism development at Ganting Beach, Simeulue Island, Aceh Province. DEPIK Jurnal IImu-IImu Perairan, Pesisir dan Perikanan, 5(1), 19-23. http:/ /dx.doi.org/10.13170/depik.5.1.3844.

Muttaqin. E., Kamal, M.M., Haryadi, S., Pardede, S., Tarigan, S., \& Campbell, S.J. (2014). Coral bleaching impacts on coral reef ecosystem in 2010 in Northern Aceh waters. Jurnal Teknologi Perikanan dan Keluatan, 5(1), $15-21$.

Pellissier, L., Leprieur, F., Parravicini, V., Cowman, P. F., Kulbicki, M., Litsios, G., ... Mouillot, D. (2014). Quaternary coral reef refugia preserved fish diversity. Science, 344(6187), 1016-1019. http:// doi.org/10.1126/science.1249853.

Plass-Johnson, J. G., Heiden, J. P., Abu, N., Lukman, M., \& Teichberg, M. (2016). Experimental analysis of the effects of consumer exclusion on recruitment and succession of a coral reef system along a water quality gradient in the Spermonde Archipelago, Indonesia. Coral Reefs, 35(1), 229243. https://doi.org/10.1007/s00338-0151369-9.

Pratchett, M. S., McCowan, D., Maynard, J. A., \& Heron, S. F. (2013). Changes in bleaching susceptibility among corals subject to ocean warming and recurrent bleaching in Moorea, French Polynesia. PLoS one, 8(7), e70443. https:/ /doi.org/10.1371/journal.pone.0070443.

Ritchie, K. B. (2006). Regulation of microbial populations by coral surface mucus and mucusassociated bacteria. Marine Ecology Progress
Series, 322, 1-14. https://doi.org/10.3354/ meps322001.

Rizwan, T., Nasution, T. K., Dewiyanti, I., Elrahimi, S. A., \& Putra, D. F. (2017). Fish diversity in the east coastal waters area of Aceh Besar District, Indonesia. Aquaculture, Aquarium, Conservation \& Legislation, 10(5), 1180-1185.

Rogers, A., Blanchard, J. L., \& Mumby, P. J. (2014). Vulnerability of coral reef fisheries to a loss of structural complexity. Current Biology, 24(9), 10001005. https://doi.org/10.1016/j.cub.2014.03.026.

Ropelewski, C. F., \& Jones, P. D. (1987). An extension of the Tahiti-Darwin southern oscillation index. Monthly Weather Review, 115(9), 2161-2165. h t t p s://doi . org/10.1175/1520 0493(1987)115\%3C2161:aeotts\%3E2.0.co;2.

Rosenberg, E., \& Ben Haim, Y. (2002). Microbial diseases of corals and global warming. Environmental microbiology, 4(6), 318-326. https:/ /doi.org/10.1046/j.1462-2920.2002.00302.x.

Rudi, E., Elrahimi, S. A., Kartawijaya, T., Herdiana, Y., Setiawan, F., Pardede, S. T.,...Tamelander, J. (2009). Reef fish status in northern Acehnese reef based on management type. Biodiversitas Journal of Biological Diversity, 10(2), 87-92. https://doi.org/ 10.13057/biodiv/d100206.

Spellerberg, I. F., \& Fedor, P. J. (2003). A tribute to Claude Shannon (1916-2001) and a plea for more rigorous use of species richness, species diversity and the 'Shannon-Wiener'Index. Global ecology and biogeography, 12(3), 177-179. https://doi.org/ 10.1046/j.1466-822x.2003.00015.x.

Sweatman, H., Burgess, S., Cheal, A., Coleman, G., Delean, S., Emslie, McDonald, A.,...Thompson, A. (2005). Long-term monitoring of the Great Barrier Reef. Status Report Number 5 2005. Australian Institute of Marine Science Publication, Townsville. Q. Australia. 261 pps. http://www.aims.gov.au/reefmonitoring.

Ulfah M. (2011). Study of coral bleaching on the condition of coral reefs and reef fish in Pulau Weh, Sabang. [Thesis]. Institut Pertanian Bogor, Bogor. [Indonesian].

Westmacott, S., Teleki, K., Wells, S., \& West, J. (2000). Pengelolaan terumbu karang yang telah memutih dan rusak kritis. Yayasan Terumbu Karang Indonesia. 
Wisha, U. J., \& Khoirunnisa, H. (2017). Sea Surface Temperature Rising Trend and Its Influence on the Coral Mortality in Pagai Strait, Mentawai Islands, Indonesia. International Journal of Civil Engineering and Technology (IJCIET), 8(10), 725-734.
Wooldridge, S. A. (2009). Water quality and coral bleaching thresholds: Formalizing the linkage for the inshore reefs of the Great Barrier Reef, Australia. Marine Pollution Bulletin, 58(5), 745-751. https://doi.org/10.1016/j.marpolbul.2008.12.013. 